Notes and later as Editor of the Journal. No major development occurred in the African continent during that time which he did not take note of and comment on freely and independently. Dr. Smith gave an account of how he came to write The Golden Stool after reading a report by Rattray, and how he completed the manuscript in three months. 'Through all my life,' he said in conclusion, 'Africa and her peoples have been my greatest interest, and if you were to open me up, you would find "Africa " written on my heart."

B. E. W.

\title{
Joint Meeting with the Royal Anthropological Institute
}

ON Is November 1944 a meeting arranged jointly by this Institute and the Royal Anthropological Institute was held, when Dr. E. W. Smith took the Chair and the Rev. G. K. Tibbatts spoke on 'Christianity and Tribal Religion in East Africa'. Mr. Tibbatts, who had been Principal of the African Teachers' Training College for Masasi Diocese, Southern Tanganyika, referred to the pioneer work done by Bishop Lucas and his interest in anthropological studies, and touched on the attitude of Christian missionaries to-day towards certain traditional African practices, in particular, the initiation ceremonies. He described the Christian form of initiation ceremony which had been adopted, with the ready co-operation of tribal chiefs and elders, in some parts of Masasi diocese, and in which, while the structure of the traditional ceremony had been preserved, the rites and some of the instruction given had been modified in accordance with Christian teaching and practice.

Mr. Tibbatts pointed out that contact with any Western ideas, or even with any Western individual, inevitably had an effect on African tribal life, and that detribalization or other disruptive consequences could not be attributed solely to the activities of missionaries. The attitude which resented any alteration in tribal customs was as mistaken as that which identified Europeanization with progress; the Africans were a living people, and while trying to conserve all that was best in tribal life, we could not refuse to admit them to the wider life which Western culture provided. The transformation of ancient custom must be carried out gradually, with the free consent and full understanding of the people concerned.

\section{Increased Participation of Basuto in Government}

Ir has been announced by the Resident Commissioner of Basutoland that the Government contemplate giving the Basuto a larger share in the administration of their country. In future, the Paramount Chief and the Basutoland Council will be consulted before laws are enacted affecting the Basuto nation. District Councils, the members of which will be Basuto, are to be established under the chairmanship of the District Commissioners, and their function will be to make recommendations to, and to elect one representative from each district for nomination as a member of the National Council, which is an advisory body of roo Basuto. The Paramount Chief and the District Commissioners are also to nominate other representatives from among the members of agricultural associations, the teaching profession, Basuto business interests, and so on. It is also announced that the Laws of Lerothodi are to be revised and published, and that this revised edition will be recognized as an authoritative statement of Basuto law and custom in all Courts of Law.

Addressing the Royal Empire Society and the Royal African Society in London on 23 January 1945, Lord Harlech, former British High Commissioner in South Africa, gave an encouraging account of the progress made in the High Commission Territories, especially in Basutoland. He stressed the differences to be observed in these territories, as indeed in all African territories, and condemned any attempt to impose a uniform policy; regard must always be paid to variations in physical environment, history, stage of development, and the potential capacity of the inhabitants. He declared his increasing belief in the right of 